\title{
リーチ運動における運動条件の違いが筋活動に及ぼす影響 \\ Effect of Motion Condition on the Muscle Activity in Reach Movement
}

\author{
学 ○上野 翔平 (阪府大院) 正 新谷 篤彦 (阪府大) \\ 正 中川 智皓 (阪府大) 米津 亮 (阪府大) 正 伊藤 智博 (阪府大)
}

Shohei UENO, Osaka Prefecture University, 1-1 Gakuencho, Naka-ward, Sakai City, Osaka Atsuhiko SHINTANI, Chihiro NAKAGAWA, Ryo YONETSU, Tomohiro ITO, Osaka Pref. Univ.

\section{1. 緒言}

立位・歩行を安定させるにはバランス感覚や各部位の 筋肉がうまく動作する必要がある。現在，それらの機能 を改善するためのリハビリテーション機器は立位状態で 使用するものが主流である，そのため，立位・歩行自体 が困難な人には転倒の危険性があるため積極的導入が困 難である.よって，転倒の危険性の少ない座位姿勢で使 用することのできるリハビリ機器が必要であると考えた. これまで, 我々は数值解析から座位でのリーチ運動にお ける筋活動を算出し，それを筋電計を用いた実験から妥 当性について検討を行ってきた。本研究では，座位の姿 勢や速度を変化させることで，筋活動にどのような影響 を及ぼすのかを検討する。

\section{2. 実 験 方 法}

被験者は身長 $175 \sim 177 \mathrm{~cm}$, 体重 $63.4 \sim 66.1 \mathrm{~kg}$ である 体型が非常によく似た 3 名の成人男性に協力してもらつ た. Fig.1にリーチ動作と実験装置を示す。まず, 被験者 は腕を伸ばし，水平に保った状態で座位姿勢で目標の向 かってリーチ運動した.リーチ距離 $l$ については, 腕の長 さ $l_{0}$ の 1.5 倍の長さとした. また, 床反力計（TF-3040-A: テック技販）を，殿部と足部にそれぞれ 1 台設置した.

リーチ運動 3 回を 1 セットとし, 3 セット行った. 比較 検討のため Table 1 のような条件で実験を行った.
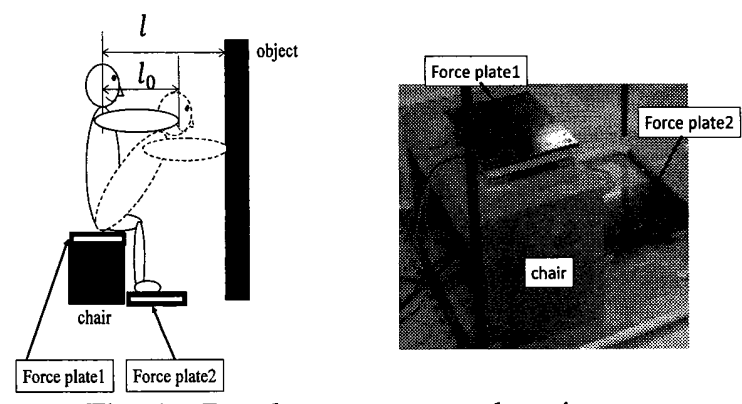

Fig. 1 Reach movement and equipment

Table 1 Experimental conditions

\begin{tabular}{c|c|c}
\hline Condi. No. & Tempo[bpm] & Knee angle[deg] \\
\hline \hline 1 & 60 & 80 \\
\hline 2 & ibid. & 90 \\
\hline 3 & ibid. & 120 \\
\hline 4 & 40 & 90 \\
\hline
\end{tabular}

ここで，リーチ速度に関しては，メトロノームを使っ てリーチ速度を規定した. 規定方法としては, 被験者に は音が鳴った際にリーチを開始し, 次の音が鳴った際に 目標に到達, さらに次の音が鳴った際に元の位置に戻っ てもらった. テンポは, 1 拍につき 1.5 秒の $40 \mathrm{bpm}$ を基 本として 1 拍につき 1 秒の $60 \mathrm{bpm}$ を速い場合とした.

このような条件下の運動を, 4 台のカメラで構成され た動作解析装置 (Kinema Tracer : キッセイコムテック社) で記録した. 被験者には, 事前に両側の肩峰, 股関節大 転子, 外果最突点, 踵, つま先の計 10 点にマーカーを貼 付した. さらに筋電計（MQ-Air：キッセイコムテック社） を用いて運動中の筋活動も記録した. 測定した筋肉は, 春 柱起立筋, 腓腹筋 (内側), ヒラメ筋の 3 箇所とした.

実験の評価方法として, 積分筋電図を用いる，積分筋 電図は，ある時間範囲にわたっての筋電計の評価指標，す なわち総放電量である. 単位は電圧 $\times$ 時間 $[\mathrm{Vs}]$ であり式 （1）で表すことができる.よって，1回のリーチ運動にか かった活動時間を $T_{e}$ として式（1）を用いて積分筋電図 を算出した．今回は, リーチ運動 3 回を 3 セット合計 9 回の平均值を求めた.

$$
i E M G=\int_{0}^{T_{e}} E M G(\tau) d \tau
$$

\section{3. 実 験 結 果}

紙面の都合上, Fig.2 に脊柱起立筋の IEMGのみを示す. 図からわかるように, 膝角度 80 度で基本速度の時に最も 大きく活動していることがわかった，また，速度による 違いや他の数值解析の結果については, 当日報告する.

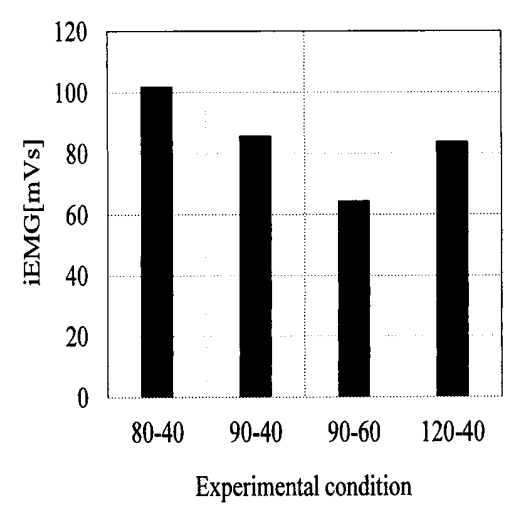

Fig. 2 iEMG of the erector spinae 